Проф. д-р Дивна Лакинска

Дипл. социјален работник Сунчица Крстевска

\title{
ОСНОВНИ КОМПОНЕНТИ ВО ИНСТИТУЦИОНАЛНАТА СОЦИЈАЛИЗАЦИЈА НА СТАРИТЕ ЛИЦА
}

UDK:364-787.9-053.9(497.7)

(со посебен осврт на искуството на социјалната работа со стари лица во ПУСЗ на стари лица „Светла надеж“")

\section{Вовед}

Згрижувањето на стари лица во приватни институции во Р. Македонија има кратка историја, но сепак, сметаме дека социјалната работа изгради солидно професионално искуство.

Во насока на овие достигнувања се вклучува и Правилникот за нормативите и стандардите за основаье и започнување со работа на установите за социјална заштита за стари лица, со што задолжително е вклучена и работата на социјален работник.

Исто така, од голема помош за работата на социјалните работници е и Правилниокот за начинот на водене на содржина и евиденцијата за корисниците од права па социјална заштита вклучувајќи ги тука и домовите за стари лица со што водењето на евиденцијата е унифицирана.

Содржината на овој труд претставува експликација на основните тематски содржини од аспект на методиката на социјалната работа во институциите за грижа на стари лица. 
Ревија за сочијална политика, год. 8, бр.11/2 Скопје, ноември 2015

\section{1. Методи на непосредна комуникација}

Социјалната работа во институциите за грижа на стари лица се карактеризира со специфични пристапи, форми и содржини, кои се реализираат низ соодветните фази во третманот на оваа категорија на популација.

Системот на институционална заштита на стари лица во Р. Македонија од 2011 год. започнува со процесот на плурализација, што подразбира лиценцирање на дотогашните приватни установи за сместување на стари лица. Со тоа старите лица, а и членовите на нивните семејства при изборот на установата во која ќе се сместат можат да бидат сигурни дека тоа се установи кои функционираат во еден систем. Тој систем гарантира одреден минимум во квалитетот и степенот на услугите. Исто така, установите подлежат на одредена контрола и се мониторирани согласно одредени стандарди.

Информацијата за услугата која ја нуди установата честопати е од суштинско значење за старото лице како и неговото семејство. На старите лица како и на нивните семејства им се потребни информации за услугите кои ги добиваат од установата, за нивните права во истата и одговорностите кои се очекуваат од нив.

Во нашата земја сѐ уште постојат предрасуди во однос на сместувањето на старите лица во установите за социјална заштита. Овие сфаќања често произлегуваат поради веќе изградениот став за животот, изградените карактери и неменувањто на навиките.Во согласност со досегашното искуство најчесто се сместуваат во случај кога веќе немаат друг избор.Доколку изборот за сместување е на старото лице, тогаш процесот на првиот контакт и адаптацијата оди многу полесно.

Доколку старото лице е свесно за ситуацијата во која се наоѓa и смета дека не може само да функционира во домашна средина, полесно се прилагодува на живот во установата.Професионалниот пристап при приемот, како вербалниот така и невербалниот говор, 
како и непосредноста на комуникацијата со социјалниот работник претставуваат битен дел во постапката за прифаќање и адаптирање.

Првата средба се базира на давање на јасни информации за услутите, дејноста и можностите за престој во установата.

Во таа насока од големо значење е подготвеноста на социјалниот работник на активно слушање, бидејќи старите лица имаат потреба да раскажуваат за своето минато. Во комуникацијата со старото лице многу е битна гестикулацијата, од страна на социјалниот работник како климнување со глава и сл., за да му се стави до знаење дека со почит и внимание се одвива разговорот. Неепотребно да има спротивставување на неговите ставови и размислувања.

Доколку тоа не е спремно сѐуште на отворен разговор при првата средба социјалниот работник потребноеда го мотивира со општи прашања кои не навлегуваат во неговата интима и кои ќе доведат да се создаде еден партнерски однос заснован на доверба.

Доста често во работата се наидува на голема недоверба од страна на семејствата на сместените корисници во установата. Понекогаш е потешко да се стекне довербата од страна на членовите на семејството отколку на самото старо лице.

Начинот на кој социјалниот работник, како реализатор на Законот за социјална заштита од овој домен, ги презентирауслугите пред семејството, влијае на атрактивноста на прифаќањето од нивна страна. Предусловите за професионалноста во работењето, се однесуваат на приодот, искреноста, нивото на почит, покажувањето на емпатијаи сл. Семејството исто како и старото лице многу го ценат професионалниот однос од целокупниот тим кој работи во установата. Стекнатата доверба во стручниот тим претставува основа во процесот на згрижување во установата, но исто така е и носител на сите постапки со корисниците, како и нивните семејства.

Во рамките на нашето истражување за следење и унапредување на квалитетот на услугите се покажаа како значајни, 
Ревија за соиијална политика, год. 8, бр.11/2 Скопје, ноември 2015

прифаќањето на нивните примедби, жалби или пофалби. Постапката за непосредна комуникација како од страна на старите лица така и од нивните членови на семејствата може да се реализира непосредносо социјалниот работникот но и со тимот кој менаџира во установата. Со оглед на тоа што голем број од корисниците се со специфична ментална и здравствена состојба, вклучувањето на семејството во ваквите истражувања е многу битно и релевантно.

За да може да ги вклучи во секојдневните активности, социјалниот работник настојувада направи успешна проценка на капацитетот на личностана старите лица, како и на состојбата во која тие се наоѓаат, со цел да се согледа кои активности реално може да се реализираат и остварат.

Процесот на оваа проценка иако се базира на темелни пристапи сепак кај старите лица, поради брзите промени во менталниот и физичкиот капацитет често пати не се дефинитивни и не наведуваат на почести проверки и дијагностицирања. Во таа насока се подразбира и почитувањето на нивнитежелби и интересикако носечки елементи во насочувањето на капацитетите за комуникација.

Проценката за напуштање на институцијата поради заминување во домашни услови или смрт ја прави тимот од установата во соработка и согласност со семејството.

Раководени од непосредните искуства сметаме дека старите лица во мал број случаи ја напуштаат установата со цел да се вратат во својата домашна средина, можеби и поради фактот што во таа насока семејството, не е во состојба да им пружи адекватна грижа.

Составен дел во процесот на постапката за сместување и престој на старото лице во установата претставува и организацијата и реализацијата на погребната постапка, се разбира во согласност со членовите на семејството. 


\section{1 Постапки за информирање и привлекување}

Со оглед на кратката историја која ја има згрижувањето на стари лица во приватните институции во Р. Македонија, од големо значење е информираноста на населението како за нивното постоење така и за услугите кои се нудат во таа институција.

Реклама која ќе биде во вид на брошура или флаер,или презентација на социјалните мрежи, може многу да допринесе како во достапноста на институциите до граѓаните така и приближување на истите до нив. На тој начин може да продолжи процесот кој веруваме дека е веќе започнат, а тоа е излегување од рамките на стигмата и табуата за установите од ваков вид.

Информациите за медицинските и социјалните услуги кои ги нуди установата се од големо значење за квалитетот и за продолжувањето на животот на старото или изнемоштено лице. Битни се информациите за целите и услугите кои ги посакуваат од установата, за стандардите и услугите во приватните установи за социјална заштита на стари лица, за нивните права и обврски кои ги имаат за периодот на сместувањето и кој е бенефитот од престој во установа.

Живееме во свет во кој електронскиот начин на комуникација и претставување, зема сѐ поголем замав, но сепак, телефонскиот начин на информирање како и информирањето „од човек на човек“ сѐ уште имаат значајна улога при процесот на достапност на заинтересираните лица.

Во приватната установа за социјална заштита на стари лица се одредува лице кое поседува комуникациски вештини за да биде достапно и секогаш правовремено да го информира семејството или старото лице во врска со сместувањето или состојбата во која се наоѓa веќе сместеното старо лице. Со достапноста се овозможува постепено стекнување на доверба, а истовремено овозможува и добра реклама. 
Ревија за соиијална политика, год. 8, бр.11/2 Скопје, ноември 2015

При сместувањето на старото лице во установата давател на услуги е самата установа а со тоа и целокупниот персонал кој работи во неа. Примател на услуги не е само старото лице туку индиректно покрај него и семејството како и околината која го познава корисникот.

Проценката на социјалниот работник при остварувањето на првиот контакт е многу битна, но не и пресудна во остварување на понатамошната соработка, сепак како појдовна основа е нужна и треба да се реализира.

Битни показатели кои учествуваат во постапката за адекватно сместување на старото лице се следниве:

$>\quad$ Собирање информачии за здравствената состојба.

$>$ Собирање на основни информащии за живот на старото лице.

Контактите на старото лице со семејството, пријателите и сл.

Начинот на кој старото лице е дојдено во установата (своеволно или на наговор од семејството).

Првата комуникација на старото лице со останатите корисници во установата.

\section{2 Професионалниот пристап на социјалниот работник}

Социјалниот работник во установата ја реализира стручната работа со корисниците пред сѐ од подрачјето на социјалната заштита, воден од принципот на транспарентност, почитување на правата на корисниците и нивните семејства, чување на професионална тајна, здравствената состојба и др. Битно е да се спомене дека при приемот потписникот на договорот потпишува ИЗЈАВА за заштита на лични податоци.

Работните задачи на социјалниот работник не се насочени само кон непоредна грижа за корисниците туку ја опфаќаат и соработката со соодветните стручни служби, семејствата или 320 
старателите на корисниците, невладините организации, и други социјално регистрирани здруженија.

Од големо значение за сите стари лица сместени во установата, а пред сѐ на интровертните кај кои доминира чувството на осаменост, се програмските ангажмани, насочени кон варијантите на непосредна соработка со поттикнување на нивните комуникациони квалитети.

Социјалната работа, како основа во процесот на згрижување, во зависност од Законот за социјална заштита се базира на изнаоѓање и реализирање на непосредни содржини за можна комуникација во изградување на чувството на прифаќање и квалитетен престој. Основните методски постапки се базираат на разговор, следење, да го забележува, почитува и следи корисникот и неговите потреби, да го гледа, набљудува, одговара, да го „погоди“ моментот кога старото лице сака „да си ја отвори душата“, пропратено со стрпливост и поддршка.

Во процесот на згрижувањето на старото лице во установата од големо значење е постапката за прифаќање и непосредно запознавање со неговата соба и неговото катче, купатилото, трпезаријата, дворот, просторијата на социјалниот работник и медицинската сестра. Со стрплива комуникација, во зависност од менталниот и социјалниот капацитет му се претставува куќниотред, со непосредно запознавање со лицата, корисници сместени во установата. Најчесто при првиот контакт најдобро би било да се запознае и комуницира со старото лице со кое најлесно може да се зближи (близина на живеење пред сместувањето, местото на семејно потекло, професија и слично) претежно со лицата кои се позитивни и спремни на соработка. Од значење е и постапката на воспоставување непосредна комуникација со старите лица во заедничката просторија која е наменета за одмор, дружење и релаксација. Со метод на набљудување социјалниот работник може да направи проценка на тоа кој со кого би можел да комуницира како и основна најчеста тема за разговор, која најчесто се однесува на минатото. При секоја следна средба корисно е да се започне истиот муабет. Лицата со отежнати 
Ревија за соиијална политика, год. 8, бр.11/2 Скопје, ноември 2015

комуникативни способности и деменција корисно би било во раката да држат бројаници или гумен предмет кој постепено ќе стане нивна преокупација, активност и самореализација.

\section{3 Професионалните пристапи за стручниот тим}

Стручниот тим во широка смисла на зборот го сочинуваат сите вработени кои се вклучени во давање услуги. Нивниот професионален и социјален пристап го изразува квалитетот на грижа од аспектна адаптација во установата, рехабилитација, оспособување за независност, социјални активности, подобрување на здравствената состојба со давање на медикаментозна терапија и др.

Значењето на семејството на старите лица, од аспект на непосредна комуникација, помага во адаптацијата во установата, во насока на поддршка на активностите на стручниот тим. Со непосредниот однос треба да помогнат во сместувањето во установата, за да остварат квалитетно стареење, а не чувстгво на отфрлање од нив. Постепено стручниот тим изградува чувство на сигурност во непосредната социјална заедница, чиј успех наметнува потреба од почитување на следните постулати:

$>\quad$ Да бидат без предрасуди.

$>\quad$ Да имаат тимски дух.

$>\quad$ Да знаат да го дадат вистинскиот одговор поткрепен со факти и чувства.

Да знаат дека промените се стресни за сите луѓе, а посебно за старите лица.

$>\quad$ Да знаат како да се однесуваат пред и откако ќе настапи смртта.

Да успеат да одржат позитивна мисла.

Она што треба често да е присутно во непосредната тимска работа со старите лица е изградувањето на способноста на слушање, на зборувањето од нивна страна, со цел да се разберат, да се открие што е доминантно во нивната свест, како и изразувањето на поддршка, чувство на почит и сигурност. Активното слушање често 
пати подразбира поставување на јасни и разбирливи прашања, како и поттикнување за добивање содржајни одговори.

Доколку се изрази одреден приговор, многу често може да се разбере како израз на внатрешен немир кој го чувствуваат. Во тој случај, соговорникот, член на стручниот тим, треба да се постави во улога на опсерватор - набљудувач, поставувајќи прашања кои ќе навлезат во реалната и суштинска причина на проблемот. Старите лица се мудри и ќе го сфатат сето тоа, а социјалниот работник само на тој начин може да постигне успех во меѓусебната комуникација.

\section{4 Постапката за изградба на критериуми и донесување одлука во процесот на сместувањето и запознавањето со дневниот ред}

\section{Потребата од категоризација и избор при сместувањето од аспект на социјална комуникација и релаксација}

Во процесот на сместување на старото лице во домот, водејќи грижа, пред сѐ од аспект на неговата здравствена состојба, семејствата често не можат или не знаат истата да ја прикажат реално, што ја налага потребата тимот во установата во постапката на прием, да направи проценка на здравствената состојба ,како и на карактерната личноста на старото лице со цел соодветно да го организира сместувањето.

Во установата потребно би било да се овозможат разновидни можности за сместување (еднокреветни, двокреветни и повеќекреветни соби). Не секогаш еднокреветните соби (апартмани),како и двокреветните се адекватно решение. Од аспект на желба за меѓусебен разговор и комуникација, како и од аспект на потреба од континуирана опсервација во текот на 24 часа, пожелно би било сместување во повеќекреветна соба со пулт на кој седи службено лице .

Од контактот со старите лица може да се заклучи дека тие кои се во свесна и со релативно добра здравствена состојба многу тешко 
Ревија за соиијална политика, год. 8, бр.11/2 Скопје, ноември 2015

се адаптираат на простор кој е мал, т.е. во еднокреветна па дури и двокреветна соба.

Старите лица кои најчесто живееле во стан со сопствена соба, соживот кој можеби вклучувал минимум $40 \mathrm{~m}^{2}$ сопствен простор, во домот се сместени во една соба од $10-15 \mathrm{~m}^{2}$ кое најчесто треба да го делат со друг и една голема заедничка дневна соба.

Од досегашното искуство во работата со старите лица може да се дојде до сознание дека двокреветните соби се најчест избор , но сепак во просторија во која заеднички живеат две лица, кои претходно меѓусебно не се познавале, при што единствено заедничко им е што се стари и изнемоштени. Во овие околности, пред сѐ, значајна улога има социјалниот работник, но и секој член на стручниот тим. Тој треба да ги согледа основните параметри на нивните личности, како и можностите за предлагање содржини за адекватно заедничко живеење.

\section{5 Основни компоненти во процесот на згрижување}

Претпоставувајќи дека животот во семејството не соодветствува потполно со животот во згрижувачка институција, а со намера да овозможиме полесна адаптација на старото лице во основа се наметнуваат следниве активности:

\subsection{1 Поддршка во вклучување во социјални активности}

За планирање на рехабилитацијата од аспект на старите лица не е доволна да се утврди само медицинската дијагноза. Потребно е да се согледа и одговори на прашањето како новонастанатата животна ситуација, болест или осаменост влијае на старото лице. Со цел да му се овозможи да го искористи потенцијалот што го има во насока на подобар квалитет на живот, се одбираат видовите на активности и постапката за вклучување во истите. 


\title{
1.5.2 Поддршка за самостојна исхрана или исхрана со помош;
}

Во својата работа во установата социјалниот работник не треба да се базира само на теоретските и практични знаења стекнати во процесот на професионалното образование. За да може професионално да ја обавува својата работа треба да воведува постојано нови инструменти на работа за да ја согледа и унапреди фактичката состојба во која се наоѓа корисникот. Од аспект на сето тоа, предлагаме непосредна примена на соодветни инструменти (тестови, скалери, еко мапи и сл.) со очекување за нивна помасовна примена. Примената на инструментите во стручната работа со старите лица претставува навика во згрижувачката постапка. Очекуваме дека примената на инструментите ќе доведат до реализирање на поквалитетна социјална заштита на старите лица.

За таа цел во прилог ги наведуваме основните инструменти во социјалната заштита на стари лица со очекување на помасовна примена.

\subsection{3 Инструменти во служба на стручната социјална работа}

No. 1 СКАЛЕР

\author{
IADL скала (Instrumental Activity of daily living) \\ ИНСТРУМЕНТ ЗА МЕРЕњЕ НА СПОСОБНОСТА ЗА \\ СЕКОЈДНЕВНО ЖИВЕЕЬЕ
}


Ревија за соиијална политика, год. 8, бр.11/2 Скопје, ноември 2015

IADL ckana (Instrumental Activity of daily living)

\begin{tabular}{|c|c|}
\hline $\begin{array}{l}\text { 1. Способност да } \\
\text { користи телефон }\end{array}$ & $\begin{array}{l}\text { 1-Се служи со телефсн со сопствена иницијатива, ти гледа и врти броеви- } \\
\text { те итн. } \\
\text { 1-Врти неколку добро познати броеви } \\
\text { 1-Одгеара на телефон, но не го користи за да повикуез од него } \\
\text { 0-Воопшто не се служи со телефон }\end{array}$ \\
\hline 2. Пазарење & $\begin{array}{l}\text { 1-Самостојно се грижи за пазарењето } \\
\text { 0-Купуеа независно само мало количестео } \\
\text { 0-Има потреба сд придрғркба за какво било пазарење } \\
\text { 0-Целосно неспособен да пазари }\end{array}$ \\
\hline $\begin{array}{l}\text { 3. Приготвуване } \\
\text { храна }\end{array}$ & $\begin{array}{l}\text { 1-Планира, приготвуеа, оервира оброци независно } \\
\text { 0-Приготвува оброци ако му се } \\
\text { достават потребните продусти } \\
\text { 0-Ги загрева и сераира приготвените сброци или приготвува оброци, но не } \\
\text { одркува адесватна исхрана } \\
\text { 0-Има потреба да му се приготеат и сераираат оброците } \\
\end{array}$ \\
\hline 4. Домахиинство & $\begin{array}{l}\text { 1-Ја одржува сам куќата или со одредена помош (тешки работи) } \\
\text { 1-Изведува лесни дсмашни задзии, како миење садови и местене кревет } \\
\text { 1-Извршува днеани задачи, но не може да одржи прифатливо ниво на } \\
\text { чистота } \\
\text { 1-Има потреба од помош за сдржување на домот } \\
\text { 0-Не учествуза во никахви задачи за одржуване на домот } \\
\end{array}$ \\
\hline 5. Перење аличта & $\begin{array}{l}\text { 1-Сам ги пере алиштата } \\
\text { 1-Пере мали парчиња (чорапи) } \\
\text { 0-Целото перење мора да го изарши друг } \\
\end{array}$ \\
\hline $\begin{array}{l}\text { 6. Насин на } \\
\text { транспорт }\end{array}$ & $\begin{array}{l}\text { 1-Самостојно патува со јавен превоз или вози автомобил } \\
\text { 1-Сам си повикува такси, но не користи јавен трзнспорт } \\
\text { 1-Патува со јавен трзнопорт со помош или во придружба } \\
\text { 0-Се користи со такси или возило со придружба } \\
\text { 0-Не патува воспшто }\end{array}$ \\
\hline $\begin{array}{l}\text { 7. Одговорност во } \\
\text { земането лекови }\end{array}$ & $\begin{array}{l}\text { 1- -даговорен е за земане лехови во тонға дози и време } \\
\text { 0-Одговорен е ако лехот му е претхсдно подготвен во поделени дози } \\
\text { 0-Не е способен да земе сопствен лех }\end{array}$ \\
\hline $\begin{array}{l}\text { 8. Способност да } \\
\text { води финансии }\end{array}$ & $\begin{array}{l}\text { 1-Самостојно ги води финансиите (бучет, иекови, плаќз кирија и сметки, } \\
\text { оди во банка), собирз и чува потврди за приход } \\
\text { 1-Самостоен во дневните купувањз, но имз потреба од помош за во банка } \\
\text { и поголеми трошоци итн. } \\
\text { 0-Не е способен да води финансии }\end{array}$ \\
\hline
\end{tabular}

IADL скалата ни ги покажува секојдневните активности на лицето непосредно по сместувањето и неговата способност за извршување на истите. Со спроведување и добивање на резултатот од оваа скала се добиваат основни информации за состојбата во која е лицето кое се сместува и колкава е неговата самостојност. 
No 2 ИНДЕКС Katz-ов ADL Индекс за процена на дневните активности

\begin{tabular}{|c|c|c|c|}
\hline Бањањe & $\begin{array}{l}\text { Не добива помош } \\
\text { (влегуаа и излегува сам, } \\
\text { ако Баната е вообичаен } \\
\text { начин на бањање) }\end{array}$ & $\begin{array}{l}\text { Добива помош само за } \\
\text { бањање на еден дел од } \\
\text { телото (на пример: грб. } \\
\text { нозе) }\end{array}$ & $\begin{array}{l}\text { Добмва помош при } \\
\text { 6ањање на повеке од } \\
\text { еден дел на телото } \\
\text { (или воопито не се } \\
\text { Бана) }\end{array}$ \\
\hline 06пекување & 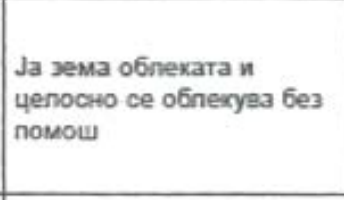 & $\begin{array}{l}\text { Ја зема облеката и } \\
\text { целосно се о6лекуаа } 6 \text { ез } \\
\text { помош, освен } \\
\text { помошта за врзување } \\
\text { врвки }\end{array}$ & $\begin{array}{l}\text { Добива помош за } \\
\text { земане на облеката } \\
\text { или облекуазые или } \\
\text { седи депумно или } \\
\text { целосно } \\
\text { необлечен }\end{array}$ \\
\hline Toanet & $\begin{array}{l}\text { Оди во тоалет, се чисти } \\
\text { и се облекува без помош } \\
\text { (мохе да жористи пома- } \\
\text { гала) }\end{array}$ & $\begin{array}{l}\text { Потребна му е помош } \\
\text { кога оди во тоалет, за } \\
\text { хигмена по тоапет и за } \\
\text { oблекуазне }\end{array}$ & $\begin{array}{l}\text { Не оди во тоалет } 33 \\
\text { аршење нулдаз }\end{array}$ \\
\hline Движење & $\begin{array}{l}\text { Седнува и станува од } \\
\text { стол и оди во и од } \\
\text { кревет без помош } \\
\text { (користејки предмет за } \\
\text { помош како стапче или } \\
\text { друго помагапо) } \\
\end{array}$ & $\begin{array}{l}\text { Седнува и станува од стоп } \\
\text { и оди во и од кревет со } \\
\text { помош }\end{array}$ & Не станувз од кревет \\
\hline Континениија & $\begin{array}{l}\text { Го контролира урини- } \\
\text { рањето и дефекацијата } \\
\text { самостојно }\end{array}$ & $\begin{array}{l}\text { Има повремени инци- } \\
\text { денти }\end{array}$ & $\begin{array}{l}\text { Помош во задршка на } \\
\text { урината и } \\
\text { дефекацијата, се } \\
\text { користи катетар } \\
\text { или е инконтинентен } \\
\end{array}$ \\
\hline Хранење & $\begin{array}{l}\text { Се храни самостојно без } \\
\text { помош }\end{array}$ & $\begin{array}{l}\text { Се храни самостојно. } \\
\text { освен при сечене месо. } \\
\text { мачкане путер на пеб }\end{array}$ & $\begin{array}{l}\text { Помош при хранење } \\
\text { или се храни депумно } \\
\text { или комплетно преку } \\
\text { сондз или интравенски } \\
\text { анесува течности }\end{array}$ \\
\hline
\end{tabular}

Katz-ов индекс социјалниот работник го изработува неколку дена после сместувањето. Истиот не го изработува сам, тоа го прави во соработка со тимот со кој работи. Тимот во установата кој се грижи за сместениот корисник е тој кој најдобро може да одговори која колона од поставените критериуми одговара на корисникот. Исто така, доколку семејството на сместениот корисник сака да си го земе во домашни услови, а социјалниот работник и тимот од установата сметаат дека во тој момент тоа не е пожелно, може да го приложи овој индекс до семејството за да истите ја согледаат состојбата во која се наоѓа старото лице. 
Ревија за сочијална политика, год. 8, бр.11/2 Скопје, ноември 2015

No.3 Barthel - Индекс за мерење на физичките функционални способности

Barthel-индекс за мерење на физичисте фунжционални способности.

\begin{tabular}{|c|c|c|}
\hline \multirow{3}{*}{ 1.Хранење } & Немовоност за самостојно хранене & 0 \\
\hline & $\begin{array}{l}\text { Има потреба од помош при сечење, мачкане путер итн. или има } \\
\text { потреба од модифицирана диега }\end{array}$ & 5 \\
\hline & Самостојно хранење & 10 \\
\hline \multirow{4}{*}{$\begin{array}{l}\text { 2.Трансфер од } \\
\text { кревет до копич- } \\
\text { ка и назад }\end{array}$} & Немолсно, нема рамнотежа за седење & 0 \\
\hline & $\begin{array}{l}\text { Патребна е поголема помош (еден или двајца, физичка помош), } \\
\text { момност за седене }\end{array}$ & 5 \\
\hline & Потребна е помала помош (вербалма или физичка) & 10 \\
\hline & Незаамсен & 15 \\
\hline \multirow{2}{*}{$\begin{array}{l}\text { 3.Надворешен } \\
\text { изгев }\end{array}$} & Има потреба од помош & 0 \\
\hline & Самостојно ( лице/коса/3a6w/бримене) & 5 \\
\hline \multirow{3}{*}{$\begin{array}{l}\text { 4. Користење } \\
\text { тоалет }\end{array}$} & Зависно & 0 \\
\hline & Има потреба од помош, но некои работи ғаи ги врши & 5 \\
\hline & Незааисно (сам седнува, станура, се облекуеа, се брише) & 10 \\
\hline \multirow{2}{*}{ 5. Kaneњe } & Зависно & 0 \\
\hline & Самостојно (или со туш) & 5 \\
\hline \multirow{4}{*}{$\begin{array}{l}\text { 6.Ниво на } \\
\text { подвисконест }\end{array}$} & Неподаикен или се двики $<50 \mathrm{~m}$ & 0 \\
\hline & Самостојно со холичика, вкпучувзјјй агти, $>50 \mathrm{~m}$ & 5 \\
\hline & Се двиоси со помеш на еден чсвек (вербална или физичха) > $50 \mathrm{~m}$ & 10 \\
\hline & $\begin{array}{l}\text { Cе двирси самостојно } 50 \mathrm{~m} \text {, мохе да користи каква било помош, на } \\
\text { пример: стап) }\end{array}$ & 15 \\
\hline \multirow{3}{*}{$\begin{array}{l}\text { 7.Качување- } \\
\text { симнуување по } \\
\text { скали } \\
\end{array}$} & Не моке да оди нагоре/надолу по скали & 0 \\
\hline & Има потреба од помош (вербална, физичика или помагало за носење ) & 5 \\
\hline & Самостојно & 10 \\
\hline \multirow{3}{*}{$\begin{array}{l}\text { 8.06пекување и } \\
\text { соблекувањье }\end{array}$} & Зависно & 0 \\
\hline & Има потреба од помош, но половина сам се обпекува & 5 \\
\hline & Самкостојно (вилучувајки копчиіьа, патенти, врвки итн.) & 10 \\
\hline \multirow{3}{*}{ 9.Lрева } & Инконтиненција (илии со потреба за клиизма) & 0 \\
\hline & Повремени инциденти & 5 \\
\hline & Континентен & 10 \\
\hline \multirow{3}{*}{ 10.Мочен меур } & Инконтинентен, или со хатетар и несамостоен & 0 \\
\hline & Повремени инциденти & 5 \\
\hline & Континентен & 10 \\
\hline
\end{tabular}

Се изготвува на почетокот од сместувањето на корисникот, односно при самиот прием. После одреден период од сместувањето се повторува. Со оваа скала социјалниот работник доаѓа до сознанија за физичката функционална состојба на корисникот. Миниментал тест 
Дивна Лакинска, Сунчища Крстевска: Основни компоненти во...

\section{No.4 ТЕСТ 3А СОСТОЈБИТЕ НА МЕНТАЛНИТЕ}

\section{СПОСОБНОСТИ}

B) Ask the subject to spell the word "WORLD" backwards. The score is the number of letters in correct position. For example, "DLROW" is 5 , "DLORW" is

3. "LROWD" is 0 .

"D"
"L"
"R"
"O"
"W"

"DLROW" or Serial 7s subtotal =

15

DELAYED VERBAL RECALL -3 points

Ask the subject to recall the 3 words you previously asked him/her to remember.

19. BALL?

20. FLAG?

21. TREE?

Delayed verbal recall subtotal $=$

13

NAMING -2 points

Show the subject a wrist watch and ask him/her what it is. Repeat for pencil.

22. WATCH

23. PENCIL

REPETITION - 1 point

Ask the subject to repeat the following :"No ifs, ands, or buts" 25. REPETITION

3-STAGE COMMAND - 3 points

Give the subject a plain piece of paper and say, "Take the paper in your hand, fold it in half, and put it on the floor."

25. TAKES

26. FOLDS

27. PUTS

READING - 1 point

Hold up the card reading, "Close your eyes", so the subject can see it clearly. Ask him/her to read it and do what it says. Score correctly only if the subject actually closes his/her eyes.

28. CLOSES EYES 


\section{WRITING 1 point}

Give subject a piece of paper and ask him/her to write a sentence. It is to be written spontaneously. It must contain a subject and verb and be sensible. Correct grammar and punctuation are not necessary. 29. SENTENCE

\section{Language subtotal $=\quad / 8$}

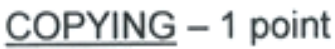

Give subject a piece of paper and ask him/he to copy a design of two intersecting shapes. One point is awarded for correctly copying it. All angles on both figures must be present, and the figures must have one overlapping angle.

Example:

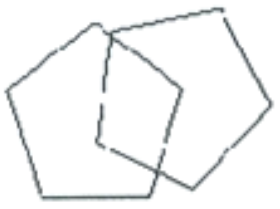

30. PENTAGONS

TOTAL MMSE = 130

$($ MMSE maximum score $=30$ )

The examination has been validated in a number of populations. Scores of 25-30 out of 30 are considered normal, 18-24 indicate mild to moderate impairment, and scores of 17 or less indicate severe impairment. 
Со изработка на мини-ментал тестот социјалниот работник доаѓa до сознанија за менталните функции и способности на старото лице.

\section{ОРИЕНТАЦИЈА - 10 поени}

1. Која дата е денеска?

2. Кој месец е?

3. Која година сме?

4. Кој ден од неделата е денеска?

5. Кое годишно време е?

6. Кое е името на установата во која сте сместени?

7. На кој кат сме?

8. Во кој град сме?

9. Во која општина е установата?

10. Во која држава живееме?

Поени-10

\section{БРЗО ПОМНЕЊЕ - 3 ПоеНИ}

Ќе ви кажам три збора, Ве молам повторете ги по мене:
11. топка,
12. знаме,
13. дрво.

\section{ПРАШАЊА ЗА ВНИМАНИЕ}

Ве молам да броите од 100 наназад, одземајќи 7:
14. 93
15. 86
16. 79
17. 72
18. 65

Ќе Ви кажам еден збор, а Вие кажете ми го од назад буква по буква:

\section{CBET \\ Поени - 5}


Ревија за сочијална политика, год. 8, бр.11/2 Скопје, ноември 2015

\section{ОДЛОЖЕНО ПОМНЕЊЕ}

Ве молам да ми ги повторите зборовите кои предмалку Ви реков да ги повторите:

19. топка,

20. знаме,

21. дрво.

$$
\text { Поени - } 3
$$

\section{ИМЕНУВАЊЕ}

На испитаникот му покажуваме часовник и пенкало и го прашуваме што е тоа:

22. часовник,

23. пенкало.

\section{ПОВТОРУВАњЕ}

Замолете го испитаникот да ја повтори по Вас реченицата:

24. без ако и или.

\section{КОМАНДА ВО ТРИ ФАЗИ}

На испитаникот му се дава лист хартија и му се кажува да ја земе во рака, да ја превитка на половина и да ја остави на подот:

25. земање,

26. држење/виткање,

27. оставање.

\section{ЧИТАЊЕ}

Му се покажува лист на кој пишува „ЗАТВОРЕТЕ ГИ ОЧИТЕ“, доколку испитаникот правилно прочита што пишува, се оценува:

28. затворете ги очите.

\section{ПИШУВАЊЕ}

На испитаникот му се дава лист на кој му се дава за задача да напише една реченица. Реченицата е по негов избор, но мора да содрижи глагол: 
29. реченица.

Поени -8

\section{ПРЕСЛИКУВАЊЕ - ЦРТАЊЕ}

Му се дава на испитаникот лист хартија и негова задача е да нацрта геометриски фигури, но истите да се преклопуваат:

30. геометриски фигури,

Поени - 1

Вкупно поени - 30

Доколку испитаникот покаже на тестод од 25 до 30 поени се смета за нормално.

Доколку покаже од 18 до 24 поени индицира дека постојат индикации за болест.

Доколку поените се под 17 тоа покажува дека веќе постои болест.

Сознанијата до кои доаѓa социјалниот работник од овие индекси и тестови му користат не само нему туку и на целиот тим кој работи во установата. Добиените резултати во голема мера помагаат во процесот на прифаќање, адаптација и престојот во институцијата.

Тестирањето се повторува некоку пати за времетраење на сместувањето за да може да се види дали е постигнат некаков напредок кај корисникот.

Детектирање на специфични потреби на старите лица како поеднинци и создавање програма за соодветна грижа

Со добиените податоци од индексите и тестовите кои ги изработува социјалниот работник во соработка со тимот од установата може да се планира примена на соодветна нега и рехабилитација. Исто така, му помага на социјалниот работник да 
Ревија за соиијална политика, год. 8, бр.11/2 Скопје, ноември 2015

планира со кој од корисниците како ќе работи и кои техники и инструменти на работа може да ги примени.

Голем бенефит и мотивација за целиот тим е напредокот кој се гледа при повторната примена на индексите.

Доста често се случува да во Katz-овиот индекс и IADLскалата при првото тестирање да се истакне првата колона, а при повторното, втората или третата или пак комбинација од повеќе колони. Или пак, на Barthel - овиот индекс или мини - ментал тестот на почетокот да се добијат пониски резултати, додека пак при повторното тестирање повисоки. Во секој случај, да се види напредок е големо задоволство и бенефит како за сместеното лице, неговото семејство така и за тимот кој работи во установата.

Социјалниот работник врз основа на добиените податоци ја организира и спроведува индивидуалната и групната работа.Исто така, можноста за примена на соодветни инструменти ја истакнува потребата од голем дијапазон на потреби, можности и видови на услуги, што создава услови за максимален ангажман во грижата за старите лицца.

Со корисниците кои имаат добиено низок коефициент на мини - ментал тестот социјалниот работник се труди да спроведува когнитивна, работна терапија и едноставни вежби кои може да го унапредат помнењето и меморијата.

Со корисниците кои покажале солидни резултати на индексите и тестовите, социјалниот работник покрај индивидуалната терапија полесно може да ги организира групните активности кои понекогаш може да се изведуваат и надвор од установата.

\section{Постапка за создавање услови за почеста комуникација со семејството и блиските}

Контактите со семејството и пријателите треба да се редовни и слободни и се остваруваат секојдневно во определен временски интервал. Времето за посета треба треба да биде флексибилно и да 334 
соодветствува со потребите и можностите на семејствата, но не и да попречи во работата на персоналот.

Социјалниот работник се труди да допринесе за одржување на врските помеѓу сместеното лице и семејството. Тој работи на адаптацијата во установата со старото лице. Што побрзо и подобро настане адаптацијата може да дојде до унапредување на нарушените односи кои може да се сретнат во семејството на корисникот.

\subsection{4 Постапката за подготовка за учество во програмата за групна работа и дневни активности}

$>\quad$ Социјалниот работник индивидуалната работа најчесто ја спроведува според потребите, употребувајќи вештини за иницијализација, актуелизација и завршеток.

Исто така, во организирањето на слободното време се реализираат специфични испланирани активности со утврдена временска рамка и распоред, во согласност со временските услови, состојбата на корисниците, соработката од тимот и сл.

Просторот во кој социјалниот работник ја организира групната работа треба да е простран и доволно некористен. Истиот не треба да потсетува на болничка соба тука на дневна соба, која по изгледот и топлината треба да е соодветна на домашна атмосфера.

\section{Заклучок}

Преминот од семејно во институционално згрижување на старите лица се базира на специфични пристапи како од аспект на прифаќање и прилагодување така и од аспект на изградување соодветна професионална работа во рамките на социјализацијата и социјалната заштита.

Во процесот на сѐ поголема масовност на оваа форма на згрижување и во недостаток на соодветни теоретски материјали за стекнување непосредни знаења, секојдневната работа на социјалните 
Ревија за соиијална политика, год. 8, бр.11/2 Скопје, ноември 2015

работници во ова подрачје придонесува за нивна лична надградба, а и во унапредување на теортските сознанија од ова подрачје на социјална заштита.

Во насока на подобрување на квалитетот на работата на социјалните работници од 2011 год. Јавната установа Завод за социјални дејности почна со обука и лиценцирање на сите стручни работници во Установите за социјална заштита, вклучувајќи ги и социјалните работници. Сето тоа придонесува за поголема успешност, професионалност и одговорност во работењето.

\section{ПОРАКА !}

Пријатното друштво и́ годи на душата на секој човек без разлика дали тој бил млад или стар. 


\section{ЛИТЕРАТУРА}

Закон за социјална заштита на Р. Македонија; (2014 амандмани)

Закон за здравствена заштита на Р. Македонија;

Зборник на научни трудови презентиран на меѓуннародната конференција

„АКТИВНО СТАРЕЕЮЕ И МЕЃУГЕНЕРАЦИСКА СОЛИДАРНОСТ“;

Тренинг програма за континуиран развој на стручните лица во системот на социјална заштита;

Скалер за мерење на способноста за секојдневно живеење

Индекс за проценка на дневните активност

Индекс за мерење на физичките функционални способности

Тест за мерење на менталните спосбности

Правилник за нормативите и стандардите за основање и започнување со работа на Установите за социјална заштита на стари лица.

Правилник за начинот на водење и содржини на евиденција на корисниците од социјална заштита. 
